\title{
FIFTY YEARS OF THE
}

\section{INTERNATIONAL GONVENTION ON}

THE ELIMINATION OF ALL FORMS OF RAGIAL DISGRIMINATION

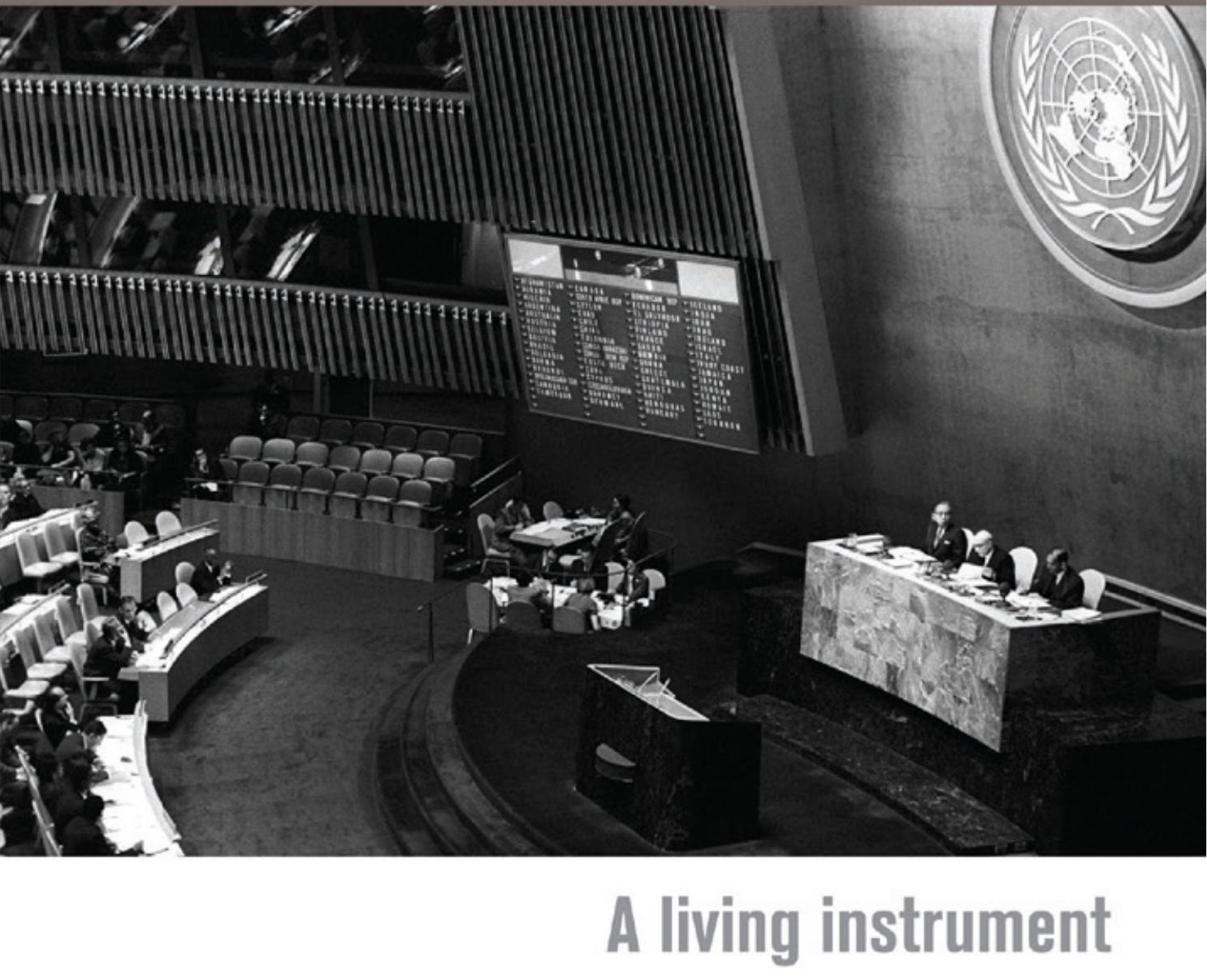

Edited by David Keane and Annapurna Waughray 
Fifty years of the International Convention on the Elimination of All Forms of Racial Discrimination

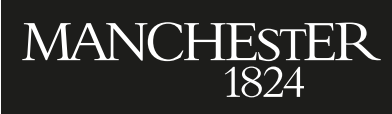

Manchester University Press 
David Keane and Annapurna Waughray - 9781526116482 Downloaded from manchesterhive.com at 04/26/2023 01:07:11PM via free access 


\section{Fifty years of the International Convention on the Elimination of All Forms of Racial Discrimination}

A living instrument

Edited by David Keane and Annapurna Waughray

Manchester University Press 
While copyright in the volume as a whole is vested in Manchester University Press, copyright in individual chapters belongs to their respective authors, and no chapter may be reproduced wholly or in part without the express permission in writing of both author and publisher.

Published by Manchester University Press

Altrincham Street, Manchester M1 7JA

www.manchesteruniversitypress.co.uk

British Library Cataloguing-in-Publication Data

A catalogue record for this book is available from the British Library

ISBN 9781784993047 hardback

First published 2017

The publisher has no responsibility for the persistence or accuracy of URLs for any external or third-party internet websites referred to in this book, and does not guarantee that any content on such websites is, or will remain, accurate or appropriate.

Typeset by Out of House Publishing

Printed in Great Britain

by CPI Group (UK) Ltd, Croydon, CR0 4YY 